\title{
Self-congruence, brand attachment and compulsive buying
}

Article

Accepted Version

Creative Commons: Attribution-Noncommercial-No Derivative Works 4.0

Japutra, A., Ekinci, Y. and Simkin, L. (2019) Self-congruence, brand attachment and compulsive buying. Journal of Business Research, 99. pp. 456-463. ISSN 0148-2963 doi:

https://doi.org/10.1016/j.jbusres.2017.08.024 Available at https://centaur.reading.ac.uk/73360/

It is advisable to refer to the publisher's version if you intend to cite from the work. See Guidance on citing.

To link to this article DOI: http://dx.doi.org/10.1016/j.jbusres.2017.08.024

Publisher: Elsevier

All outputs in CentAUR are protected by Intellectual Property Rights law, including copyright law. Copyright and IPR is retained by the creators or other copyright holders. Terms and conditions for use of this material are defined in the End User Agreement.

\section{www.reading.ac.uk/centaur}

\section{CentAUR}

Central Archive at the University of Reading

Reading's research outputs online 


\title{
Self-congruence, brand attachment and compulsive buying
}

\author{
Arnold Japutra $^{\mathrm{a}, *}$, Yuksel Ekinci ${ }^{\mathrm{b}}$, Lyndon Simkin ${ }^{\mathrm{c}}$ \\ a Business School, University of Western Australia, Australia \\ b Business School, University of Portsmouth, United Kingdom \\ c Centre for Business in Society, Coventry University, United Kingdom
}

\section{A R T I C L E I N F O}

\section{Keywords:}

Actual self-congruence

Ideal self-congruence

Brand attachment

Impulsive buying

Obsessive-compulsive buying

\begin{abstract}
A B S T R A C T
Compulsive buying refers to a phenomenon that promotes excessive consumerism which may hurt the brands' reputation in the long run. This study examines the influence of actual and ideal self-congruence on brand attachment and two dimensions of compulsive buying behavior (i.e. impulsive and obsessive-compulsive buying). Based on a survey of 427 respondents, it is evident that self-congruence directly affects brand attachment, where actual self-congruence is a stronger predictor of brand attachment. Both actual and ideal selfcongruence do not directly affect obsessive-compulsive buying. This indicates that brand attachment fully mediates the relationships. However, actual self-congruence directly affects impulsive buying but ideal selfcongruence does not. This indicates that brand attachment partially mediates the relationship between actual self-congruence and impulsive buying and fully mediates the relationship between ideal self-congruence and impulsive buying. Interestingly, the direct effect of actual self-congruence on impulsive buying is negative. Academic and managerial implications of these findings are discussed.
\end{abstract}

\section{Introduction}

Compulsive buying refers to a condition when consumers have the tendency to conduct repetitive buying excessively and display a shortfall of impulse control over buying. This form of behavior includes both obsessive-compulsive and impulse-control disorders (Ridgway, KukarKinney, \& Monroe, 2008). Compulsive buying has been of interest to consumer researchers in recent years (e.g. Darrat, Darrat, \& Amyx, 2016; Kukar-Kinney, Scheinbaum, \& Schaefers, 2016; Ridgway et al., 2008). Gallagher, Watt, Weaver, and Murphy (2017) note that although shopping has been regarded as a necessity and harmless, compulsive buying may lead to many undesirable consequences, including severe personal debt and damaged family relationships.

Previous research has investigated the factors that lead to compulsive buying behavior. For instance, Achtziger, Hubert, Kenning, Raab, and Reisch (2015) show that lower levels of self-control are associated with higher levels of compulsive buying. Other research shows that hedonic motivation is related to compulsive buying (Kukar-Kinney et al., 2016). Our research puts forward self-congruence as the driver of compulsive buying. Self-congruence was chosen because firms have been using the actual and ideal self-concept to communicate and attract consumers to their brands (Malär, Krohmer, Hoyer, \& Nyffenegger, 2011). For instance, Unilever's Dove line has used real people who are average in appearance for their advertisements to correspond to how consumers actually see themselves (i.e. actual self-concept). On the other hand, L'Oreal has used celebrities (e.g. Beyonce) in its communications to correspond to how consumers would like to see themselves (i.e. ideal self-concept).

Research on the relationships between self-congruence and negative behavior, such as compulsive behavior, is also limited (c.f. Hosany \& Martin, 2012). Previous studies primarily focus on the relationship between self-congruence and positive outcomes, such as consumer loyalty (i.e. intention to recommend or intention to purchase). In investigating compulsive buying, extant research largely examines the impact of ideal self-concept motivation, not the actual self-concept (e.g. Dittmar, 2005a; Dittmar, Long, \& Bond, 2007). Research that touches upon the actual self-concept focuses solely on the discrepancy between the actual and ideal self-concept (e.g. Dittmar, 2005b; Xu, 2008).

This new study examines the ideal self-concept, but also examines the actual self-concept. This study goes further by examining the notion of self-congruence, which reflects the consumers' perception of the fit between the self-concept (actual or ideal) and the brands' personality or image (Malär et al., 2011). Two research questions that arise are: Do actual and ideal self-congruence lead to compulsive buying? Which one of the two has a greater contribution in predicting compulsive buying? This research investigates the link between self-congruence and compulsive buying behavior to address this deficiency in the literature.

\footnotetext{
* Corresponding author

E-mail addresses: arnold.japutra@uwa.edu.au (A. Japutra), yuksel.ekinci@port.ac.uk (Y. Ekinci), lyndon.simkin@coventry.ac.uk (L. Simkin).
} 
In addition to investigating the impact of self-congruence on compulsive buying behavior, this study puts forward brand attachment as a mediating variable between self-congruence and compulsive buying behavior. Although brand attachment is considered to provide firms with positive consequences (e.g. Japutra, Ekinci, \& Simkin, 2016; Thomson, MacInnis, \& Park, 2005), it can also stimulate negative consequences (e.g. Japutra, Ekinci, Simkin, \& Nguyen, 2014; Johnson, Matear, \& Thomson, 2011). In this study, brand attachment refers to the strength of the emotional link that connects the consumer and the brand, involving feelings toward the brand (Malär et al., 2011). Thus, the propensity to conduct compulsive buying may be influenced by the strength of the attachment between consumers and brands.

The contribution of this study is three-fold. First, this study investigates the link between actual and ideal self-congruence in two forms of compulsive buying behavior: impulse buying and obsessivecompulsive purchasing. To the best of our knowledge, there is no study that has investigated whether actual or ideal self-congruence contributes more in predicting compulsive buying behavior. Second, this study examines the effect of brand attachment on compulsive buying. Previous studies have advocated the importance of building stronger attachment that leads to favorable behaviors, such as loyalty (e.g. Japutra et al., 2016; Park, MacInnis, Priester, Eisingerich, \& Iacobucci, 2010; Thomson et al., 2005). However, recent qualitative studies have started to show that brand attachment may also lead to unfavorable behaviors, such as trash talking and schadenfreude (e.g. Japutra et al., 2014; Johnson et al., 2011). To the best of our knowledge, there are no empirical studies focusing on the relationship between self-congruence, brand attachment and compulsive buying. It is argued that practitioners use self-congruence to build strong emotional brand attachment (Malär et al., 2011). Thus, it is important to understand the negative consequences of self-congruence and brand attachment, since negative behaviors (i.e. compulsive buying) can be harmful for the brands in the long run (Gallagher et al., 2017).

Third, this study examines the mediating effect of brand attachment on the relationship between self-congruence and compulsive buying behavior. It is argued that the effects of self-congruence in influencing many consumer behaviors are indirect (e.g. Nam, Ekinci, \& Whyatt, 2011; Roy \& Rabbanee, 2015). Self-congruence may not directly influence compulsive buying, since the present of strong attachment may alter the direct effect. From a managerial perspective, this study offers insights into the impact of using self-congruence in marketing activities on consumers' propensity to conduct compulsive buying.

\section{Conceptual background}

Ridgway et al. (2008) define compulsive buying as a preoccupation on buying that is repetitive and uncontrolled. Compulsive consumers are vulnerable, since they display a lack of impulse control over shopping (Kukar-Kinney et al., 2016). As a result, compulsive consumers may end up with high level of debt as well as social and family problems (Achtziger et al., 2015; O'Guinn \& Faber, 1989).

Most compulsive buyers exhibit preoccupation in their repetitive shopping, as in obsessive behavior (e.g. Faber \& O'guinn, 1992). Compulsive buying is shown to have a positive correlation with three facets of impulsivity: urgency, lack of perseverance and lack of premeditation (Billieux, Rochat, Rebetez, \& Van der Linden, 2008). Dittmar (2005b) reports three factors that drive compulsive buying: materialistic values, self-discrepancies and ideal-self buying motivation. Meanwhile, Gallagher et al. (2017) note that compulsive buying occurs because there is a state of impaired functioning in individuals and they would like to reduce negative emotional arousal. Duroy, Gorse \& Lejoyeux (2014) suggest that individuals conduct compulsive buying due to loss of control, temptations from firms (i.e. sale events) and immediate positive feelings.

Compulsive buying displays two forms of behavior: impulsive buying and obsessive-compulsive buying (Ridgway et al., 2008). An impulse-control disorder (ICD) represents inevitable impulses to conduct harmful behaviors, whereas obsessive-compulsive disorder (OCD) represents anxiety disorder, with obsessions (thoughts and preoccupations) and compulsions (behavior) that activate distress and anxiety, dissipate large amounts of time, and intervene with an individual's everyday functioning. in this study, impulsive buying refers to an unplanned purchase that is accompanied by rapid decision-making and subjective bias in favor of immediate possession, where consumers buy spontaneously, unreflectively, immediately and kinetically (Kacen \& Lee, 2002; Rook \& Fisher, 1995). On the other hand, obsessive-compulsive buying refers to an uncontrolled urge that is accompanied by preoccupation in buying and repetitive buying in order to reduce anxiety (Ridgway et al., 2008).

Drawing on the self-concept theory, individuals possess two different types of self-concept: the actual self and the ideal self (Escalas \& Bettman, 2003; Malär et al., 2011). The actual self represents the state where individuals consider who they really are, whereas the ideal self represents the state of individuals' aspirations of their ideas and goals in the future. The actual and ideal self-concept serve as the basis of the self-congruence theory. Self-congruence refers to the fit between consumers' self-concept and brand personality (Aaker, 1999; Sirgy, 1982). Actual self-congruence refers to the degree of fit between the brands' personality to foster consumers' conception of who they really are, whereas ideal self-congruence refers to the degree of fit between the brands' personality to foster consumers' aspiration of who they would like to be in the future.

Brand attachment covers the emotional bonding between the consumer and the brand, which includes three basic feelings: passion, affection and connection (Thomson et al., 2005). in this study, brand attachment refers to the strength of the emotional link that connects the consumer and the brand, involving feelings toward the brand (Malär et al., 2011). Extant research displays that being attached to brands increases the tendency to purchase the brands' products, which may end up in compulsive buying (e.g. Horváth \& Birgelen, 2015; Kaufmann, Petrovici, Gonçalves Filho, \& Ayres, 2016). Thus, brand attachment may mediate the relationship between self-congruence (i.e. actual and ideal) and compulsive buying behavior (i.e. impulsive and obsessivecompulsive buying).

Drawing on the self-concept and brand attachment theory, Fig. 1 displays the conceptual framework linking self-congruence, overall brand attachment and compulsive buying behavior.

As shown on the conceptual framework, actual (H1) and ideal selfcongruence (H2) are positively related to overall brand attachment. Then overall brand attachment is positively related to impulsive buying (H3) and obsessive-compulsive buying (H4). Hence, the conceptual framework states that overall brand attachment fully mediates the relationships between the two self-congruencies and two compulsive buying behaviors. Also the research model in Fig. 1 posits a partial mediation model including four research hypotheses, where actual (H5a-H5b) and ideal self-congruence (H6a-H6b) are positively related to consumers' tendency to conduct impulsive and obsessive-compulsive buying.

\section{Development of hypotheses}

\subsection{Self-congruence and brand attachment}

Consumers use brands to express their actual or ideal self-concept (Aaker, 1999; Ekinci, Sirakaya-Turk, \& Preciado, 2013). For expressing their actual self, consumers are being guided by a self-verification motive, whereas for expressing their ideal self, consumers are being guided by a self-enhancement motive (Escalas \& Bettman, 2003). For instance, a female consumer who considers herself as a socially responsible person would purchase Body Shop products that help her in reflecting her actual self-concept (i.e. socially responsible). On the other hand, the same consumer would purchase Armani products in order to 


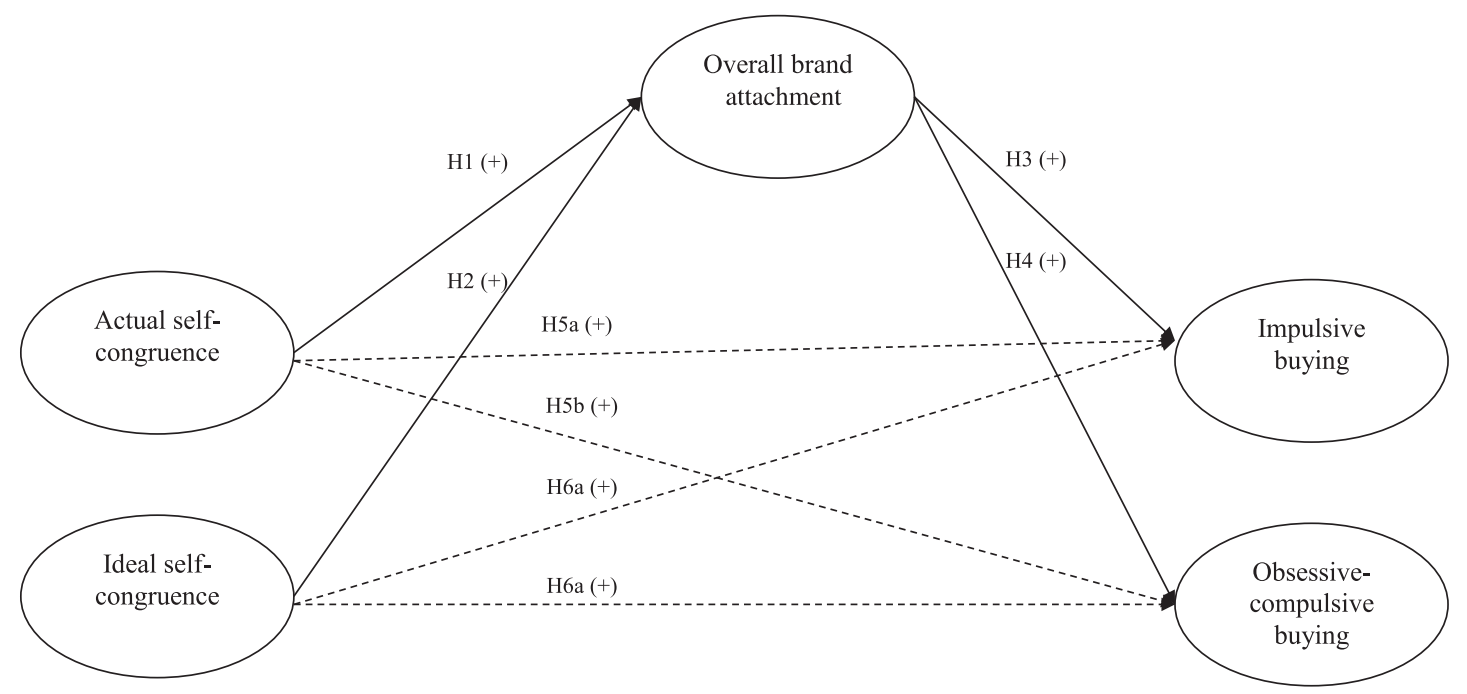

Fig. 1. Conceptual framework.

promote her ideal self-concept, which may be formed by a trendy and outgoing image.

Kressmann et al. (2006) show that the brand relationship quality is enhanced, when brands are able to trigger self-verification and selfenhancement motives. Hence, the stronger match between brand image and the actual or ideal self-concept, the stronger the emotional bonding toward the brand (Malär et al., 2011). Previous research offers evidence that social media users are attached to social media brands when brand image is congruent with their actual or ideal self-concept (Hollenbeck \& Kaikati, 2012). This new study posits that when the congruity between brand image and the actual or ideal self-concept is high, consumers will feel that the brand fosters their self-verification or self-enhancement motivation. Accordingly, consumers will become attached to the brand. Thus, this study proposes the following hypotheses:

H1. Actual self-congruence positively affects brand attachment.

H2. Ideal self-congruence positively affects brand attachment.

\subsection{Brand attachment and compulsive buying behavior}

In a recent study, it is evident that compulsive respondents display emotional bonding with brands (Horváth \& Birgelen, 2015). Rindfleisch, Burroughs, and Wong (2009) note that consumers are attached to particular brands because they are materialistic and anxious with their existence needing symbolic security. Previous studies show that materialism and the tendency to conduct compulsive buying are significantly correlated (Johnson \& Attmann, 2009; Reeves, Baker, \& Truluck, 2012). Pieters (2013) notes that individuals who failed to obtain interpersonal attachment rely on material possessions as secondary attachment. They do this in order to provide themselves with a sense of comfort and security (Chaplin, Hill \& John 2014). In other words, individuals become materialistic to reduce their anxiety. According to Roberts and Jones (2001), anxiety increases compulsive buying behavior. Moreover, individuals who are strongly attached to a brand tend to spend more resources (e.g. time or money) for the brand (Park et al., 2010). Hence, stronger brand attachment may lead to higher compulsive buying tendency.

Recently, Kaufmann et al. (2016) show that consumers who display higher brand attachment are more likely to purchase products of the brand, either originals or counterfeits. Kessous, Roux, and Chandon (2015) argue that brand attachments have connections to the nostalgic status of the brand. Brands are capable of evoking a consumer's nostalgic experiences by taking the consumer to a particular past event that s/he embraces (Loveland, Smeesters, \& Mandel, 2010). If brands are capable of promoting nostalgic experiences, consumers will be strongly attached to these brands and increase their propensity to collect brand artifacts (Kessous et al., 2015). Thus, this study posits these hypotheses:

H3. Brand attachment positively affects impulsive buying.

H4. Brand attachment positively affects obsessive-compulsive buying.

\subsection{The mediating role of brand attachment}

This study postulates that self-congruence is indirectly related to two forms of compulsive behavior (i.e. impulsive and obsessive-compulsive buying). Brand attachment is proposed as the mediating component that increases consumers' tendency to conduct compulsive buying due to two reasons. First, it is shown that brand affect partially mediates the link between the urge to buy and compulsive buying (Flight, Rountree, \& Beatty, 2012). Extant research considers brand attachment as a "hot affect" rather than "cold affect" (c.f. Park et al., 2010; Malär et al., 2011). Second, in the compulsive hoarding behavior literature, attachment is regarded as playing a prominent role (Grisham et al., 2009). Although compulsive hoarding is considered distinct from compulsive buying, it is argued that the two are associated (Mueller, Mitchell, Crosby, Glaesmer, \& de Zwaan, 2009). Thus, brand attachment may have a mediating role on compulsive buying behavior. According to Escalas and Bettman (2003), brands foster consumer's selfverification and self-enhancement motives. Consumers are strongly attached to a brand if the brand is congruent with their actual or ideal self-concept (Malär et al., 2011). When consumers strongly attach to brands, they enjoy purchasing the brands compulsively (Kessous et al., 2015).

In order to test for the mediation effect of brand attachment, this study posits the link between self-congruence (actual and ideal) and the two forms of compulsive buying (impulsive and obsessive-compulsive). This relationship has received limited investigation, as most research only examines the role of ideal self-concept motivation on compulsive buying. For instance, Dittmar (2005a) shows that ideal self-concept buying motivation mediates the relationship between materialistic values and compulsive buying tendency. She argues that individuals who regard material possessions to enhance their ideal self-concept highly, have higher prevalence to compulsive buying. Previous research shows that consumers' willingness to close the gap between the actual and ideal self-concept discrepancy influences compulsive buying (c.f. Verplanken \& Sato, 2011). This means that actual and ideal self-congruence may directly influence impulsive and obsessive-compulsive 
buying.

Desarbo and Edwards (1996) show that when consumers feel a high level of excitement and impulsiveness, they tend to conduct compulsive buying. Furthermore, Zhang, Howell, and Howell (2014) show that greater neighborhood social economic status increases material desires, which predicts more frequent impulsive buying. A stronger congruity between brand personality and actual or ideal self-concept creates a state of excitement, since the brands help them in achieving consumers' actual or desired self-image. Thus, a higher level of self-congruence may increase the tendency for consumers to engage with compulsive buying behavior. Compulsive consumers purchase products to satisfy their self-concept needs and improve their social image (Kukar-Kinney, Ridgway, \& Monroe, 2012). Thus, this study posits these hypotheses:

H5a. Actual self-congruence positively affects impulsive buying.

H5b. Actual self-congruence positively affects obsessive-compulsive buying.

H6a. Ideal self-congruence positively affects impulsive buying.

H6b. Ideal self-congruence positively affects obsessive-compulsive buying.

\section{Method}

\subsection{Measures}

A questionnaire was developed to test the study's research hypotheses. The measurement items were adapted from existing scales. In order to refine the questionnaire, twelve British consumers were invited to pre-test the questionnaire.

Following previous studies (e.g. Ekinci, Dawes, \& Massey, 2008; Nam et al., 2011), self-congruence was measured using a direct-score formula. Six items adapted from Malär et al. (2011) and Sirgy et al. (1997), were used to measure actual and ideal self-congruence. In the questionnaire, the respondents were asked to read a scenario-like paragraph to measure self-congruence as shown below:

"Take a moment to think about your favorite brand. Think about the kind of person who typically uses this brand. Imagine this person in your mind and then describe this person using one or more personal adjectives such as, stylish, classy, masculine, sexy, old, athletic, or whatever personal adjectives you can use to describe the typical user of this brand."

After reading the scenario-like paragraph, respondents were asked to rate the actual and ideal self-congruence statements on a 7-point scale anchored by (1) = strongly disagree and (7) = strongly agree. Following Malär et al.'s (2011) study, overall brand attachment was assessed using six items on a 7-point scale anchored by (1) = not at all and (7) = completely. However, based on the pre-testing stage, the item "love" was changed to "friendliness". Following Ridgway et al.'s (2008) study, obsessive-compulsive buying and impulsive buying were measured using three items and a 7-point scale anchored by (1) = not very likely and $(7)=$ very likely (see Table 1 for the measures).

\subsection{Data collection and sample}

The questionnaire was distributed through a mail survey with a return pre-paid envelope. Different housing locations in the Southeast of UK were selected as the target of the mail survey. According to Ahn, Ekinci, and Li (2013), the Southeast region includes the most representative and demographically diverse residents of the UK population. In total, 5000 questionnaires were distributed and as many as 434 questionnaire were returned. Of these, 427 were retained for further analysis.

The demographic profiles of the respondents were: $60.9 \%$ were women. For occupation, $37.5 \%$ worked as professionals (e.g. managers, directors, senior officials), $23 \%$ were students, and $11.2 \%$ of the respondents had retired. The respondents' educational backgrounds were: $31.4 \%$ have obtained undergraduate degrees, $27.9 \%$ have obtained master's degree, $16.4 \%$ have obtained A-level or equivalent, and $10.5 \%$ have obtained a doctoral degree. Most of these respondents reported income of less than $£ 10,000$ (23.9\%), $£ 10,000$ to $£ 29,999$ (32.3\%), $£ 30,000$ to $£ 59,999$ (22.3\%), and above $£ 60,000$ (8.0\%). In terms of age group, $20.6 \%$ were in the age group of $16-24,35.1 \%$ were in the age group of $25-44$, and $31.4 \%$ were in the age group of $45-64$.

\section{Results}

\subsection{Reliability and validity of the measures}

The study used the Partial Least Square-Structural Equation Modeling (PLS-SEM) approach for data analysis, The PLS-SEM was run using Smart PLS 3.0 software. Hair, Ringle, and Sarstedt (2011) note that PLS has less restrictive assumptions and able to address a wide range of problems efficiently with a much wider range of sample sizes.

A two-stage approach, evaluating the outer model and then the inner model, was followed (Hair et al., 2011; Hair, Sarstedt, Hopkins, \& Kuppelwieser, 2014). The outer model evaluation was performed through the PLS-SEM algorithm to assess the reliability and validity of the measures. The inner model evaluation was performed through a bootstrapping procedure (5000 subsamples) to test the research hypotheses.

Reliability was checked using the composite reliability score. Reliability is achieved when the Composite Reliability (CR) value exceeds 0.60 (Bagozzi \& Yi, 1988). The results from the PLS-SEM algorithm reveal that reliability was achieved, since the CR scores exceeded the threshold. Next, the convergent validity was checked. According to Fornell and Larcker (1981), convergent validity is achieved if the Average Variance Extracted (AVE) value exceeds 0.50 and each item has outer loadings above 0.70 (Hair et al., 2014). An item of impulsive was duly removed, since the outer loading was below the recommended threshold. After removing the item, the results showed that convergent validity was achieved, since the AVE scores and outer loadings exceeded the threshold.

After confirming the convergent validity, the discriminant validity was checked using Fornell and Larcker's (1981) approach. If the square root of the AVE score is above the inter-correlation (IC), discriminant validity is achieved. Table 2 displays IC and square root of the AVE scores.

The IC scores were below the square root of the AVE scores, indicating that discriminant validity was achieved. Before testing the research hypotheses, common-method variance was checked. This is because in a study such as this, where data on both the antecedents and consequences are collected using similar types of response scales (e.g. Likert scales) from the same respondents, common-method variance may pose a problem (Du, Bhattacharya, \& Sen, 2007). Based on previous research (Du et al., 2007; Podsakoff, MacKenzie, Lee, \& Podsakoff, 2003), common-method variance was checked using Harman's singlefactor test, which suggests that common-method variance poses a problem if (1) a single unrotated factor solution appears from the EFA test, or (2) one general factor accounts for the majority of the covariance among the measures. Based on the data, the unrotated factor solution revealed 4 factors with Eigen values $>1$. The result accounts for $69.27 \%$ of the total variance, where the first factor accounts for $32.87 \%$ of the total variance. This suggests that common-method variance does not pose a significant problem. There was no general factor in the unrotated structure (Du et al., 2007).

\subsection{Hypotheses testing}

After confirming the reliability and validity of the measures, a bootstrapping procedure (5000 subsamples) was conducted to test the 
Table 1

Descriptive, reliability and convergent validity.

\begin{tabular}{|c|c|c|c|c|c|c|}
\hline Composite & Factor loading & Mean & SD & $\mathrm{CR}$ & AVE & Item \\
\hline \multirow[t]{4}{*}{ Actual self-congruence } & & 4.39 & 1.27 & 0.83 & 0.62 & \\
\hline & 0.87 & & & & & This brand is consistent with how I see myself. \\
\hline & 0.75 & & & & & This brand is a mirror image of me. \\
\hline & 0.72 & & & & & This brand is similar to me. \\
\hline \multirow[t]{4}{*}{ Ideal self-congruence } & & 4.32 & 1.42 & 0.89 & 0.74 & \\
\hline & 0.75 & & & & & This brand is a mirror image of the person I would like to be. \\
\hline & 0.90 & & & & & This brand is similar to the person I would like to be. \\
\hline & 0.92 & & & & & This brand is consistent with how I would like to be. \\
\hline \multirow[t]{7}{*}{ Overall brand attachment } & & 3.96 & 1.42 & 0.91 & 0.64 & \\
\hline & 0.77 & & & & & Affection \\
\hline & 0.81 & & & & & Friendliness \\
\hline & 0.61 & & & & & Connected to \\
\hline & 0.86 & & & & & Passion \\
\hline & 0.87 & & & & & Delight \\
\hline & 0.84 & & & & & Captivation \\
\hline \multirow[t]{3}{*}{ Impulsive buying } & & 2.27 & 1.44 & 0.79 & 0.65 & \\
\hline & 0.89 & & & & & I buy things from this brand that I don't need \\
\hline & 0.71 & & & & & I consider myself an impulse purchaser for this brand \\
\hline \multirow[t]{4}{*}{ Obsessive-compulsive buying } & & 1.74 & 1.32 & 0.84 & 0.65 & \\
\hline & 0.79 & & & & & My closet has unopened shopping bags of this brand in it \\
\hline & 0.89 & & & & & Others might consider me a shopaholic for this brand \\
\hline & 0.72 & & & & & Much of my life centers around buying things from this brand \\
\hline
\end{tabular}

Note: SD: Standard Deviation; CR: Composite Reliability; AVE: Average Variances Extracted.

Table 2

Average Variance Extracted (AVE) and Inter-Correlations (IC).

\begin{tabular}{llllll}
\hline & 1 & 2 & 3 & 4 & 5 \\
\hline 1. Actual self-congruence & $\mathbf{0 . 7 9}$ & & & & \\
2. Ideal self-congruence & 0.77 & $\mathbf{0 . 8 6}$ & & & \\
3.Overall brand attachment & 0.36 & 0.34 & $\mathbf{0 . 8 0}$ & & \\
4. Impulsive buying & 0.05 & 0.11 & 0.35 & $\mathbf{0 . 8 1}$ & \\
5. Obsessive-compulsive buying & 0.06 & 0.07 & 0.41 & 0.72 & $\mathbf{0 . 8 0}$
\end{tabular}

Note: The diagonal scores (in bold) indicate the square root of AVEs.

Table 3

Results of the hypotheses testing.

\begin{tabular}{|c|c|c|c|c|c|}
\hline & \multirow[t]{2}{*}{ Path } & \multicolumn{2}{|c|}{ Full mediation } & \multicolumn{2}{|c|}{ Partial mediation } \\
\hline & & SPC & t-value & SPC & t-value \\
\hline H1: & $\begin{array}{l}\text { Actual self-congruence } \rightarrow \text { Overall } \\
\text { brand attachment }\end{array}$ & 0.24 & $2.85^{* *}$ & 0.24 & $2.73^{* *}$ \\
\hline $\mathrm{H} 2:$ & $\begin{array}{l}\text { Ideal self-congruence } \rightarrow \text { Overall } \\
\text { brand attachment }\end{array}$ & 0.15 & 1.84 & 0.16 & $1.88^{*}$ \\
\hline H3: & $\begin{array}{l}\text { Overall brand attachment } \rightarrow \\
\text { Impulsive buying }\end{array}$ & 0.35 & $9.19^{* * *}$ & 0.37 & $8.21^{* * * *}$ \\
\hline H4: & $\begin{array}{l}\text { Overall brand attachment } \rightarrow \\
\text { Obsessive-compulsive buying }\end{array}$ & 0.41 & $11.78^{* * *}$ & 0.44 & $12.13^{* * * *}$ \\
\hline H5a: & $\begin{array}{l}\text { Actual self-congruence } \rightarrow \\
\text { Impulsive buying }\end{array}$ & & & -0.17 & $2.21^{*}$ \\
\hline H5b: & $\begin{array}{l}\text { Actual self-congruence } \rightarrow \\
\text { Obsessive-compulsive buying }\end{array}$ & & & -0.08 & $0.99^{\text {ns }}$ \\
\hline H6a: & $\begin{array}{l}\text { Ideal self-congruence } \rightarrow \text { Impulsive } \\
\text { buying }\end{array}$ & & & 0.11 & $1.10^{\mathrm{ns}}$ \\
\hline H6b: & $\begin{array}{l}\text { Ideal self-congruence } \rightarrow \text { Obsessive- } \\
\text { compulsive buying }\end{array}$ & & & -0.03 & $0.32^{\mathrm{ns}}$ \\
\hline \multicolumn{6}{|c|}{ Variance explained } \\
\hline \multicolumn{2}{|c|}{ Overall brand attachment } & \multicolumn{2}{|l|}{$14.4 \%$} & \multicolumn{2}{|l|}{$14.6 \%$} \\
\hline \multicolumn{2}{|c|}{ Impulsive buying } & \multicolumn{2}{|l|}{$12.5 \%$} & \multicolumn{2}{|l|}{$14.3 \%$} \\
\hline \multicolumn{2}{|c|}{ Obsessive-compulsive buying } & \multicolumn{2}{|l|}{$16.9 \%$} & \multicolumn{2}{|l|}{$18.3 \%$} \\
\hline
\end{tabular}

Note: SPC $=$ Standardized Path Coefficient

ns not significant.

${ }^{*} p<0.05$.

*** $p<0.01$.

**** $p<0.001$ research hypotheses. For this study's purposes, two models were tested: the full mediation model and the partial mediation model. In the partial mediation model, the paths between actual and ideal self-congruence on impulsive buying and obsessive-compulsive buying are available, whereas these paths are not available in the full mediation model. Table 3 shows results of the model and hypotheses testing.

As can be seen from the results, actual and ideal self-congruence explain $14.4 \%$ and $14.6 \%$ respectively of the variance in overall brand attachment in the full and partial mediation model. On the other hand, $12.5 \%$ (full mediation model) and $14.3 \%$ (partial mediation model) of the variance in impulsive buying is explained by actual self-congruence, ideal self-congruence and overall brand attachment. Subsequently, 16.9\% (full mediation model) and $18.3 \%$ (partial mediation model) of the variance in obsessive-compulsive buying is explained by actual selfcongruence, ideal self-congruence and overall brand attachment.

The results support $\mathrm{H} 1$ and $\mathrm{H} 2$, that actual self-congruence (SPC $=0.24, p<0.01)$ and ideal self-congruence $(\mathrm{SPC}=0.16$, $p<0.05$ ) have positive relationships with overall brand attachment. The results also reveal that actual self-congruence is a better predictor of overall brand attachment than ideal self-congruence. H3 proposed that overall brand attachment has a positive relationship with impulsive buying. This hypothesis is supported by the link that is statistically significant (SPC $=0.37, p<0.001$ ). The results also support $\mathrm{H} 4$, which proposed that overall brand attachment has a positive relationship with obsessive-compulsive buying (SPC $=0.44, p<0.001$ ). When consumers display high brand attachment, they display higher propensity to conduct impulsive and obsessive-compulsive buying behavior.

The results show that actual self-congruence influences impulsive buying (SPC $=-0.17, p<0.05$ ). This means that overall brand attachment partially mediates the relationship. However, the direction of the link is not as expected. Instead of positive, the relationship between actual self-congruence and impulsive buying is negative. This means that higher congruity between the consumer's actual self and the brand results in a lower tendency to conduct impulsive buying. Hence, H5a is not supported. H5b proposes that actual self-congruence positively influences obsessive-compulsive buying. The results do not support $\mathrm{H} 5 \mathrm{~b}$ (SPC $=-0.08, p>0.05)$. The results also do not support H6a $(\mathrm{SPC}=0.11, p>0.05)$ and $\mathrm{H} 6 \mathrm{~b}(\mathrm{SPC}=-0.03, p>0.05)$. Ideal self-congruence does not positively influence impulsive and obsessivecompulsive buying. As expected, this means that overall brand 
Table 4

Mediating effects of the partial mediation model.

Bias corrected bootstrap 95\%

confidence interval

\begin{tabular}{|c|c|c|c|c|c|}
\hline Path & $\begin{array}{l}\text { Indirect } \\
\text { effect }\end{array}$ & SE & t-value & Lower & Upper \\
\hline $\begin{array}{l}\mathrm{ASC} \rightarrow \mathrm{OBA} \rightarrow \\
\mathrm{IB}\end{array}$ & 0.089 & 0.035 & $2.502^{* *}$ & 0.017 & 0.159 \\
\hline $\begin{array}{c}\mathrm{ASC} \rightarrow \mathrm{OBA} \rightarrow \\
\mathrm{OCB}\end{array}$ & 0.107 & 0.041 & $2.591^{* * *}$ & 0.022 & 0.183 \\
\hline $\begin{array}{l}\text { ISC } \rightarrow \text { OBA } \rightarrow \\
\text { IB }\end{array}$ & 0.060 & 0.032 & $1.839^{*}$ & 0.001 & 0.126 \\
\hline $\begin{array}{c}\mathrm{ISC} \underset{\mathrm{OCB}}{\rightarrow} \mathrm{OBA} \rightarrow \\
\rightarrow\end{array}$ & 0.072 & 0.038 & $1.846^{*}$ & 0.001 & 0.149 \\
\hline
\end{tabular}

Note: bootstrapping based on $n=5000$ subsamples; ASC: Actual self-congruence; ISC: Ideal self-congruence; OBA: Overall brand attachment; IB: Impulsive buying; OCB: Obsessive-compulsive buying.

${ }^{*} p<0.05$.

${ }^{* *} p<0.01$.

attachment fully mediates the relationship between actual self-congruence on obsessive-compulsive buying and ideal self-congruence on impulsive and obsessive-compulsive buying. To further test the mediation analysis, we checked the indirect effect and bias-corrected 95\% bootstrap confidence interval (CI) from the PLS output. It is suggested that the SEM approach is superior to Baron and Kenny's approach in testing mediation effect, since it estimates everything simultaneously (Zhao, Lynch, \& Chen, 2010).

First, we checked the mediation effect of overall brand attachment on actual self-congruence, impulsive buying and obsessive-compulsive buying (see Table 4). The confidence interval for the indirect effect of actual self-congruence on impulsive buying excludes zero $(95 \%$ CI $[0.017,0.159])$. The results show that overall brand attachment mediates the relationship between actual self-congruence and impulsive buying. The direct effect of actual self-congruence on impulsive buying is also significant ( $\mathrm{SPC}=-0.17, p<0.05$ ) and since $\mathrm{a} \times \mathrm{b} \times \mathrm{c}$ $(-0.081)$ is negative; it is a competitive mediation (Zhao et al., 2010). The confidence interval for the indirect effect of actual self-congruence on obsessive-compulsive buying excludes zero (95\% CI [0.022, 0.183]). The results show that overall brand attachment mediates the relationship between actual self-congruence and obsessive-compulsive buying. Since the direct effect of actual self-congruence on obsessive-compulsive buying is not significant (SPC $=-0.08, p>0.05$ ), it is an indirect-only mediation (Zhao et al., 2010).

Next, we checked the mediation effect of overall brand attachment on ideal self-congruence, impulsive buying and obsessive-compulsive buying (see Table 4). The confidence interval for the indirect effect of ideal self-congruence on impulsive buying excludes zero $(95 \%$ CI $[0.001,0.126])$. The results show that overall brand attachment mediates the relationship between ideal self-congruence and impulsive buying. Since the direct effect of ideal self-congruence on impulsive buying is not significant (SPC $=0.11, p>0.05$ ), it is an indirect-only mediation (Zhao et al., 2010). The confidence interval for the indirect effect of ideal self-congruence on obsessive-compulsive buying excludes zero (95\% CI $[0.001,0.149])$. The results show that overall brand attachment mediates the relationship between ideal self-congruence and obsessive-compulsive buying. Since the direct effect of ideal self-congruence on obsessive-compulsive buying is not significant (SPC $=-0.03, p>0.05$ ), it is an indirect-only mediation (Zhao et al., 2010).

\section{Conclusion}

Material consumption, particularly compulsive buying, decreases individual economic and subjective well-being (Zhang et al., 2014). Compulsive buying may accompany consumers with severe debts
(Achtziger et al., 2015; Gallagher et al., 2017). When this occurs, brands will also face consequences, since their consumers are unable to pay but continue purchasing these products. Thus, it is important for brands and policy makers to understand the factors that will lead to compulsive buying behavior.

This study extends the body of knowledge related to brand attachment and compulsive buying behavior. First, the results enlighten which type of self-congruence is more important to build stronger brand attachment. We support Malär et al.'s (2011) findings that actual self-congruence is a better predictor of brand attachment. Second, this study put forward brand attachment as an important mediator of the link between self-congruence and compulsive buying behavior. This study's findings show that brand attachment fully mediates the relationship between actual self-congruence and ideal self-congruence on impulsive and obsessive-compulsive buying except for the relationship between actual self-congruence and impulsive buying, where brand attachment only partially mediates the link. This finding supports a growing number of previous studies that proposed indirect relationships between self-congruence and brand behaviors (Çifci et al., 2016; Nam et al., 2011). These studies found that brand satisfaction is required to trigger positive consumer behavior (i.e. brand loyalty). In line with the previous studies, this study reveals that the relationships between self-congruence and the two forms of compulsive buying need strong emotions (i.e. brand attachment) to trigger negative consumer behaviors.

Third, we also highlight that actual self-congruence directly affects impulsive buying behavior. Interestingly, the results show that actual self-congruence has an opposite influence on impulsive buying. This study finds that higher actual self-congruence will result in a lower propensity to conduct impulsive buying behavior. This might be due to several reasons. The first is that the consumers who participated in this survey were consumers that have high utilitarian value. It has been shown that hedonic value and not utilitarian value leads to compulsive buying (Kukar-Kinney et al., 2016). Another explanation might be due to these consumers have actual self-concept that reduces compulsive buying (i.e. low in neuroticism). In the fashion context, Johnson and Attmann (2009) found that neuroticism leads to compulsive buying. They noted that highly neurotic consumers tend to be worrisome, nervous, emotional, insecure, inadequate, hypochondriacal, anxious, self-pitying, tense, touchy and unstable; whereas low neurotic consumers tend to be calm, relaxed, unemotional, hardy, secure, self-satisfied, even-tempered and unflappable.

Brands should consider using excessive communications that foster exaggeration to consumers' ideal-self. For instance, advertisements featuring thin or 'under-weight' models are related to adolescent girls' body dissatisfaction and eating disorders (Bell, Lawton, \& Dittmar, 2007; Halliwell, Dittmar, \& Howe, 2005). Hence, this study is useful for policy makers. Policy makers should regulate brands, such as the creation of advertisements that magnify fostering their ideal-self that is full of embellishment.

Horváth and Birgelen (2015) note that when brands condone compulsive buying, they are facing ethical dilemmas due to their social responsibilities. If most people consider the brand as an irresponsible brand, brand managers should be aware of the declining brand reputation. Kotler (2011) advocates that the world of marketing is changing and consumers are fond of how brands meet their social responsibilities. In particular, he argues that consumers do not always think that more consumption and wanting satisfaction increase their quality of life and personal happiness. Thus, brands should not encourage compulsive buying, as this is only advantageous in the shortrun.

\section{Limitations and future research}

Although this study adds to the body of knowledge, it is not without its limitations. The first limitation is related to the sample size of this 
study. Second, the respondents of this study were UK consumers. Thus, it is hard to generalize the results of this study for consumers with different cultural backgrounds. Future studies should increase the sample size and replicate the model elsewhere, in order to enhance its generalizability.

Further studies should also account for other variables that would influence compulsive buying behavior. For instance, researchers could include materialism and level of anxiety (Reeves et al., 2012; Rindfleisch et al., 2009) in the model. Park et al. (2010) argue that brand attachment not only includes emotional bonding, but also includes cognitive bonding. They note that brand-self connection and brand prominence are dimensions of brand attachment. It would also be of interest to find out which components of brand attachment (brandself connection or brand prominence) have greater importance on the two forms of compulsive buying. It would also be worthwhile to investigate the effect of self-discrepancy between the ideal and self-congruence on the relationships. Finally, it would be of interest to understand the negative link between actual self-congruence and impulsive buying. Future research could explore the consumers' value (i.e. hedonic vs. utilitarian) and personality (i.e. neuroticism).

\section{References}

Aaker, J. (1999). The malleable self: The role of self-expression in persuasion. Journal of Marketing Research, 36(2), 45-57.

Achtziger, A., Hubert, M., Kenning, P., Raab, G., \& Reisch, L. (2015). Debt out of control: The links between self-control, compulsive buying, and real debts. Journal of Economic Psychology, 49, 141-149.

Ahn, T., Ekinci, Y., \& Li, G. (2013). Self-congruence, functional congruence, and destination choice. Journal of Business Research, 66(6), 719-723.

Bagozzi, R. P., \& Yi, Y. (1988). On the evaluation of structural equation models. Journal of the Academy of Marketing Science, 16(1), 74-94.

Bell, B. T., Lawton, R., \& Dittmar, H. (2007). The impact of thin models in music videos on adolescent girls' body dissatisfaction. Body Image, 4(2), 137-145.

Billieux, J., Rochat, L., Rebetez, M. M. L., \& Van der Linden, M. (2008). Are all facets of impulsivity related to self-reported compulsive buying behavior? Personality and Individual Differences, 44(6), 1432-1442.

Chaplin, L. N., Hill, R. P., \& John, D. R. (2014). Poverty and materialism: A look at impoverished versus affluent children. Journal of Public Policy \& Marketing, 33(1) 78-92.

Çifci, S., Ekinci, Y., Whyatt, G., Japutra, A., Molinillo, S., \& Siala, H. (2016). A cross validation of Consumer-Based Brand Equity models: Driving customer equity in retail brands. Journal of Business Research, 69(9), 3740-3747.

Darrat, A. A., Darrat, M. A., \& Amyx, D. (2016). How impulse buying influences compulsive buying: The central role of consumer anxiety and escapism. Journal of Retailing and Consumer Services, 31, 103-108.

Desarbo, W. S., \& Edwards, E. A. (1996). Typologies of compulsive buying behavior: A constrained clusterwise regression approach. Journal of Consumer Psychology, 5(3), 231-262.

Dittmar, H. (2005a). Compulsive buying-a growing concern? An examination of gender, age, and endorsement of materialistic values as predictors. British Journal of Psychology, 96(4), 467-491.

Dittmar, H. (2005b). A new look at "compulsive buying": Self-discrepancies and materialistic values as predictors of compulsive buying tendency. Journal of Social and Clinical Psychology, 24(6), 832.

Dittmar, H., Long, K., \& Bond, R. (2007). When a better self is only a button click away: Associations between materialistic values, emotional and identity-related buying motives, and compulsive buying tendency online. Journal of Social and Clinical Psychology, 26(3), 334-361.

Du, S., Bhattacharya, C. B., \& Sen, S. (2007). Reaping relational rewards from corporate social responsibility: The role of competitive positioning. International Journal of Research in Marketing, 24(3), 224-241.

Duroy, D., Gorse, P., \& Lejoyeux, M. (2014). Characteristics of online compulsive buying in Parisian students. Addictive behaviors, 39(12), 1827-1830.

Ekinci, Y., Dawes, P. L., \& Massey, G. R. (2008). An extended model of the antecedents and consequences of consumer satisfaction for hospitality services. European Journal of Marketing, 42(1/2), 35-68.

Ekinci, Y., Sirakaya-Turk, E., \& Preciado, S. (2013). Symbolic consumption of tourism destination brands. Journal of Business Research, 66(6), 711-718.

Escalas, J. E., \& Bettman, J. R. (2003). You are what they eat: The influence of reference groups on Consumers' connections to brands. Journal of Consumer Psychology, 13(3), 339-348.

Faber, R. J., \& O'guinn, T. C. (1992). A clinical screener for compulsive buying. Journal of Consumer Research, 19(3), 459-469.

Flight, R. L., Rountree, M. M., \& Beatty, S. E. (2012). Feeling the urge: Affect in impulsive and compulsive buying. Journal of Marketing Theory and Practice, 20(4), 453-466.

Fornell, C., \& Larcker, D. F. (1981). Evaluating structural equation models with unobservable variables and measurement error. Journal of Marketing Research, 39-50.

Gallagher, C. E., Watt, M. C., Weaver, A. D., \& Murphy, K. A. (2017). "I fear, therefore, I shop!" exploring anxiety sensitivity in relation to compulsive buying. Personality and Individual Differences, 104, 37-42.

Grisham, J. R., Frost, R. O., Steketee, G., Kim, H. J., Tarkoff, A., \& Hood, S. (2009). Formation of attachment to possessions in compulsive hoarding. Journal of Anxiety Disorders, 23(3), 357-361.

Hair, J. F., Ringle, C. M., \& Sarstedt, M. (2011). PLS-SEM: Indeed a silver bullet. Journal of Marketing Theory and Practice, 19(2), 139-152.

Hair, J. F., Sarstedt, M., Hopkins, L., \& Kuppelwieser, V. G. (2014). Partial least squares structural equation modeling (PLS-SEM) an emerging tool in business research. European Business Review, 26(2), 106-121.

Halliwell, E., Dittmar, H., \& Howe, J. (2005). The impact of advertisements featuring ultra-thin or average-size models on women with a history of eating disorders. Journal of Community and Applied Social Psychology, 15(5), 406-413.

Hollenbeck, C. R., \& Kaikati, A. M. (2012). Consumers' use of brands to reflect their actual and ideal selves on Facebook. International Journal of Research in Marketing, 29(4), 395-405.

Horváth, C., \& Birgelen, M. V. (2015). The role of brands in the behavior and purchase decisions of compulsive versus noncompulsive buyers. European Journal of Marketing, 49(1/2), 2-21.

Hosany, S., \& Martin, D. (2012). Self-image congruence in consumer behavior. Journal of Business Research, 65(5), 685-691.

Japutra, A., Ekinci, Y., \& Simkin, L. (2016). Tie the knot: Building stronger consumers' attachment toward a brand. Journal of Strategic Marketing, 1-18.

Japutra, A., Ekinci, Y., Simkin, L., \& Nguyen, B. (2014). The dark side of brand attachment: A conceptual framework of brand attachment's detrimental outcomes. The Marketing Review, 14(3), 245-264.

Johnson, A. R., Matear, M., \& Thomson, M. (2011). A coal in the heart: Self-relevance as a post-exit predictor of consumer anti-brand actions. Journal of Consumer Research, 38(1), 108-125.

Johnson, T., \& Attmann, J. (2009). Compulsive buying in a product specific context: Clothing. Journal of Fashion Marketing and Management, 13(3), 394-405.

Kacen, J. J., \& Lee, J. A. (2002). The influence of culture on consumer impulsive buying behavior. Journal of Consumer Psychology, 12(2), 163-176.

Kaufmann, H. R., Petrovici, D. A., Gonçalves Filho, C., \& Ayres, A. (2016). Identifying moderators of brand attachment for driving customer purchase intention of original vs counterfeits of luxury brands. Journal of Business Research, 69(12), 5735-5747.

Kessous, A., Roux, E., \& Chandon, J. L. (2015). Consumer-brand relationships: A contrast of nostalgic and non-nostalgic brands. Psychology and Marketing, 32(2), 187-202.

Kotler, P. (2011). Reinventing marketing to manage the environmental imperative. Journal of Marketing, 75(4), 132-135.

Kressmann, F., Sirgy, M. J., Herrmann, A., Huber, F., Huber, S., \& Lee, D. J. (2006). Direct and indirect effects of self-image congruence on brand loyalty. Journal of Business Research, 59(9), 955-964.

Kukar-Kinney, M., Ridgway, N. M., \& Monroe, K. B. (2012). The role of price in the behavior and purchase decisions of compulsive buyers. Journal of Retailing, 88(1), 63-71.

Kukar-Kinney, M., Scheinbaum, A. C., \& Schaefers, T. (2016). Compulsive buying in online daily deal settings: An investigation of motivations and contextual elements. Journal of Business Research, 69(2), 691-699.

Loveland, K. E., Smeesters, D., \& Mandel, N. (2010). Still preoccupied with 1995: The need to belong and preference for nostalgic products. Journal of Consumer Research, 37(3), 393-408.

Malär, L., Krohmer, H., Hoyer, W. D., \& Nyffenegger, B. (2011). Emotional brand attachment and brand personality: The relative importance of the actual and the ideal self. Journal of Marketing, 75(4), 35-52.

Mueller, A., Mitchell, J. E., Crosby, R. D., Glaesmer, H., \& de Zwaan, M. (2009). The prevalence of compulsive hoarding and its association with compulsive buying in a German population-based sample. Behaviour Research and Therapy, 47(8), 705-709.

Nam, J., Ekinci, Y., \& Whyatt, G. (2011). Brand equity, brand loyalty and consumer satisfaction. Annals of Tourism Research, 38(3), 1009-1030.

O'Guinn, T. C., \& Faber, R. J. (1989). Compulsive buying: A phenomenological exploration. Journal of Consumer Research, 147-157.

Park, C. W., MacInnis, D. J., Priester, J., Eisingerich, A. B., \& Iacobucci, D. (2010). Brand attachment and brand attitude strength: Conceptual and empirical differentiation of two critical brand equity drivers. Journal of Marketing, 74(6), 1-17.

Pieters, R. (2013). Bidirectional dynamics of materialism and loneliness: Not just a vicious cycle. Journal of Consumer Research, 40(4), 615-631.

Podsakoff, P. M., MacKenzie, S. B., Lee, J. Y., \& Podsakoff, N. P. (2003). Common method biases in behavioral research: A critical review of the literature and recommended remedies. Journal of Applied Psychology, 88(5), 879.

Reeves, R. A., Baker, G. A., \& Truluck, C. S. (2012). Celebrity worship, materialism, compulsive buying, and the empty self. Psychology and Marketing, 29(9), 674-679.

Ridgway, N. M., Kukar-Kinney, M., \& Monroe, K. B. (2008). An expanded conceptualization and a new measure of compulsive buying. Journal of Consumer Research, 35(4), 622-639.

Rindfleisch, A., Burroughs, J. E., \& Wong, N. (2009). The safety of objects: Materialism, existential insecurity, and brand connection. Journal of Consumer Research, 36(1), $1-16$.

Roberts, J. A., \& Jones, E. (2001). Money attitudes, credit card use, and compulsive buying among American college students. Journal of Consumer Affairs, 35(2), 213-240.

Rook, D. W., \& Fisher, R. J. (1995). Normative influences on impulsive buying behavior. Journal of Consumer Research, 22(3), 305-313.

Roy, R., \& Rabbanee, F. K. (2015). Antecedents and consequences of self-congruity. European Journal of Marketing, 49(3/4), 444-466.

Sirgy, M. J. (1982). Self-concept in consumer behavior: A critical review. Journal of 
Consumer Research, 287-300.

Sirgy, M. J., Grewal, D., Mangleburg, T. F., Park, J. O., Chon, K. S., Claiborne, C. B., \& Berkman, H. (1997). Assessing the predictive validity of two methods of measurin self-image congruence. Journal of the Academy of Marketing Science, 25(3), 229-241.

Thomson, M., MacInnis, D. J., \& Park, C. W. (2005). The ties that bind: Measuring the strength of consumers' emotional attachments to brands. Journal of Consumer Psychology, 15(1), 77-91.

Verplanken, B., \& Sato, A. (2011). The psychology of impulse buying: An integrative self- regulation approach. Journal of Consumer Policy, 34(2), 197-210.

$\mathrm{Xu}, \mathrm{Y}$. (2008). The influence of public self-consciousness and materialism on young consumers' compulsive buying. Young Consumers, 9(1), 37-48.

Zhang, J. W., Howell, R. T., \& Howell, C. J. (2014). Living in wealthy neighborhoods increases material desires and maladaptive consumption. Journal of Consumer Culture, 1469540514521085.

Zhao, X., Lynch, J. G., \& Chen, Q. (2010). Reconsidering Baron and Kenny: Myths and truths about mediation analysis. Journal of Consumer Research, 37(2), 197-206. 